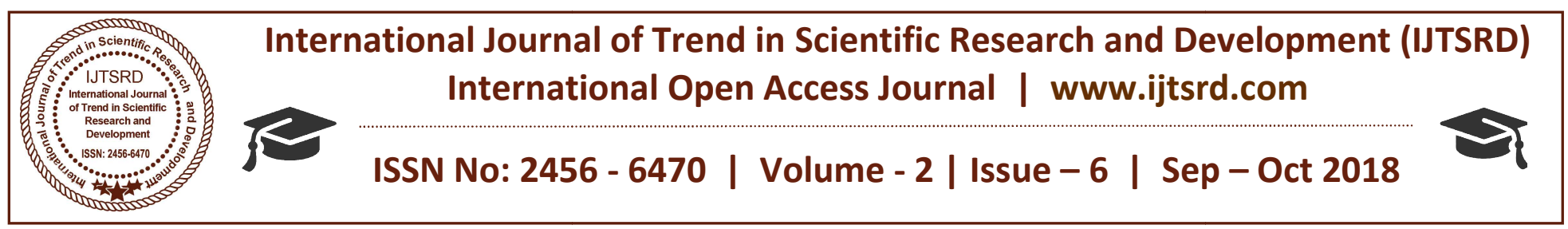

\title{
A Review Paper on Sloping Ground Building Structures under Seismic \& Wind Load Conditions
}

\author{
Abhishek Kumar ${ }^{1}$, Pratiksha Malviya ${ }^{2}$ \\ ${ }^{1}$ M.Tech Scholar, ${ }^{2}$ Professor, \\ Department of Civil Engineering, Millennium Institute of Technology \& Science, \\ Bhopal, Madhya Pradesh, India
}

\begin{abstract}
Analysis and design of space building frame for seismic loading and wind pressure is very essential these days because construction of high rise buildings. It is also necessary to construct an economic and more durable structure. It is possible by availability of various software and specialized programs. By using these software we can design a low weight reinforce structure which life is very good. These structures are more economical and safe by different forces acting on the building structure such as seismic load, snow load and wind pressure etc.

The current work examines the structural behavior of reinforced concrete columns, beam and footing in sloping geometry. In this study a $\mathrm{G}+8$ storey $\mathrm{RCC}$ building is analysed on varying sloping angles i.e., 0 o or plane surface, $10 \mathrm{o}$ and $15^{\circ}$.
\end{abstract}

Keyword: sloping ground, STAAD Pro v8i, shear force, bending moment, axial force, shear force, seismic zone.

\section{INTRODUCTION}

Earthquakes occur when energy stored in elastically strained rocks is suddenly released. This arrival of vitality causes extreme ground shaking in the region close to the wellspring of the quake and sends wave of flexible vitality called seismic waves all through the earth. Most regular tremor are caused by sudden slippage along a blame zone. The flexible bounce back hypothesis proposes that if slippage along blame is stuck to such an extent that versatile strain vitality develops in the twisting rocks on either side of the blame when the slippage occurs the vitality discharged causes a seismic tremor. At the point when a quake happens, the versatile vitality is discharged and conveys vibration that movements all through the earth. These vibrations are additionally called seismic waves. The investigation of how waves act in the earth is called seismology. The wellspring of a tremor is known as the Center, which is a correct area inside the earth were seismic waves are created by sudden arrival of put away flexible vitality. The epicenter is the point on the surface of the earth straightforwardly over the core interest.

\section{SHORT COLUMN AND LONG COLUMN}

Due to site conditions, buildings on hill-slopes have unequal column heights which results in variation of column stiffness. In buildings with unequal vertical member (i.e. column) also the floors twist about a vertical axis and displace horizontally and suffered more damage in the shorter columns as compared to taller columns in the same storey. This particular effect is known as short column effect and the short columns are subjected to severe damage during strong ground shaking.

A seismic design of high rise buildings has assumed considerable importance in recent times. In traditional methods adopted based on fundamental mode of the structure and distribution of earthquake forces as static forces at various stories may be adequate for structures of small height subjected to earthquake of very low Intensity but as the number of stories increases the seismic design demands more rigorous.

During past earthquakes, reinforced concrete (RC) frame buildings that have columns of different heights within one storey, suffered more damage in the shorter columns as compared to taller columns in the same storey. One example of buildings with short 
columns in buildings on a sloping ground can be seen in the figure (1.3) given below.

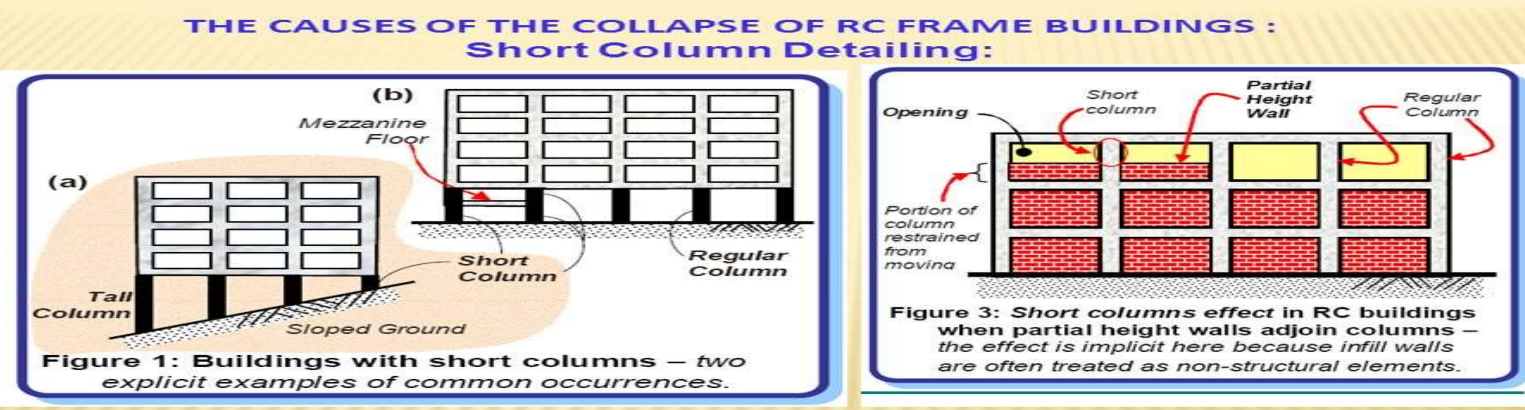

Fig 1.3: Building frame with short columns

\section{STAAD-pro V8i:-}

STAAD pro is the leading design and structural analysis software developed in Yorba Linda, CA by Research Engineers International. In the late months of year 2005, Research Engineers was brought by Bentley Systems. It is quite user friendly and supports a number of steel, timber and concrete design codes. It can make utilization of different manifestations of structural analysis from the conventional first order static analysis, second order p-delta investigation and geometrical non-linear analysis. These models can be used in different forms of dynamic analysis from model extraction and response spectrum to time history analysis.

STAAD.pro provides a very interactive user interface that allows users to draw frame sections and input load values and dimensions. According to specified specifications, it analyzes the structure and finally designs the members with reinforcement details for the RCC frame.

\section{Methods of Analysis:}

Analysis is performed on the basis of behaviour of the structure, external action, structural material and the type of selected structural model. Depending on the type of behaviour of the external verb and structure, the analysis can be further classified as given below.

\section{Equivalent static analysis:}

All designs against earthquake load should be considered on the dynamic nature of the load. However, for ordinary general structures, analysis by parallel linear analysis method is sufficient. This is allowed in most exercises for regular, low-rise buildings. Dynamic analysis is not included in this system; however, it is estimated to be responsible for the mobilization of the project. Firstly, the design base shear is calculated for the entire building, and then it is circulated with the height of the building. At each floor level, thus obtained, the lateral forces are distributed for different side load resistance elements. (Duggal S.K., 2010)

\section{Nonlinear Static Analysis:}

This is a convenient method in which the analysis is done under permanent vertical load and it gradually increases the lateral load to estimate the pattern of distortion and damage to the structure. Nonlinear static investigation is the technique for seismic examination in which the structure is spoken to by the conduct bend, which demonstrates the connection between the base shear and the uprooting of the rooftop. It is otherwise called false examination.

\section{Response Spectrum Method:}

In this method, peak responses of a structure are received directly by earthquake responses during earthquake.

\section{Literature Survey}

Several studies have been made to investigate the structural performance of building frame resting on sloping ground. The effect in terms of axial force, shear force, moment support reaction, and displacement are studied for more realistic analysis to quantify the effects of various slope of ground.

Chandrasekaran and Rao (2002) investigated analysis and the design of multi- storied RCC buildings for seismicity. Reinforced concrete multistoried buildings are very complex to model as structural systems for analysis. Usually, they are modeled as two- dimensional or three-dimensional frame systems are in plane and slope with different 
angles $5^{\circ}, 10^{\circ}$, and $15^{\circ}$. A case history of a $\mathrm{RC}$ structure, involved in the study, is briefly cited in the paper. The current version of the IS: 1893 - 2002 requires that practically all multistoried buildings be analyzed as three-dimensional systems. This is due to the fact that the buildings have generally irregularities in plan or elevation or in both. Further, seismic intensities have been upgraded in weaker zones as compared to the last version IS: 1893-1984. It has now indirectly become mandatory to analyze all multistoried buildings in the country for seismic forces and comparing the axial force, shear force, moment, nodal displacement, stress in beam and support reaction. This paper appraises briefly the significant changes in the current version of the code compared to the previous version.

Birajdar B.G. (2004) introduced the outcomes from seismic investigations performed on $24 \mathrm{RC}$ structures with three unique setups like, Advance back building; Advance back Set back building and Set back building are displayed. $3-\mathrm{D}$ investigation including torsional impact has been completed by utilizing reaction range technique. The dynamic reaction properties

i.e. basic day and age, top story removal and, the base shear activity actuated in sections have been examined with reference to the appropriateness of a building arrangement on inclining ground. It is seen that Progression back Set back structures are observed to be more appropriate on sloping ground.

Kadid A. also, Boumrkik A. (2005) contemplated trial weakling investigation was completed with an examination the execution of encircled structures under future expected seismic tremors. Slanting ground is thinking about the three confined structures with 5, 8 and 12 stories separately were dissected. The outcomes acquired in these three structures and think about the pivotal power, bowing minute, nodal relocation, base shear and demonstrates that appropriately planned casings will perform well under seismic codes by the authors are the push over analysis is a relatively simple way to explore the linear

Y. Singh and Phani Gade (2011) The structures in bumpy zones must be arranged contrastingly because of shortage of level ground. This paper introduces a few perceptions about seismic conduct of slope structures amid the Sikkim quake of September 18,
2011. A scientific examination is additionally performed to explore the impossible to miss seismic conduct of slope structures. Dynamic reaction of slope structures is contrasted and that of standard structures on level ground in wording essential time of vibration, example of between story float, segment shear, and plastic pivot development design. The seismic conduct of two run of the mill arrangements of slope structures is researched utilizing straight and nondirect time history investigation. It is seen that slope structures have altogether unexpected unique qualities in comparison to structures on level ground. The narratives promptly over the street level, if there should be an occurrence of down-slope structures, are especially helpless against quake activity. The scientific discoveries are authenticated by the harm design saw amid Sikkim seismic tremor.

Yimeng Yang (2012) Confronting countless compose complex auxiliary framework and dynamically perfect tremor safe speculations, the ordinary programming can never again address the issues of estimation and investigation. In the mean time, some worldwide limited component programs, for example, ETABS, SAP2000, MIDAS/gen and SATWE, were refreshing themselves yet stayed separate constraints. In this paper, reaction range, time history and connecting section in-plan stresses investigation were executed joined with a down to earth venture by these projects, which were additionally thought about after the examination results.

Mohammed Umar Farooque Patel (2012) considered the structures on slope contrast from different structures. The different floors of such building ventures back towards the slope incline and atthesametimebuildingsmayhavesetbacksalso.Buildin gssituatedinhillyareasae and more helpless against seismic condition. In this examination, 3D investigative model of eight storied structures have been created for symmetric and asymmetric building Models and dissected utilizing auxiliary investigation to ETABS" to contemplate the impact of shifting stature of sections in ground story because of slanting ground and the impact of shear divider at various positions amid seismic tremor. Seismic investigation has been finished utilizing Direct Static, Straight Powerful technique and assessed utilizing sucker examination Eight Storied building situated in zone III of medium soil locales has been broke down. Concentrate the status of the plastic pivots framed at various areas in the structure when the structure 
achieves its execution point. It is in this way vital to consider the condition of pivots in the structure at performance point.

KeyvanRamin (2015) examined the exploratory demonstrating and numerical displaying for a fourstory strengthened solid building that the examination of basic 3-D casings of changing floor statures and shifting number of straights with various incline edges utilizing an extremely mainstream programming instrument STAAD Professional on both a slanting and a level part. Additionally Sap2000 programming had been utilized to demonstrate that the uprooting of floors is more prominent for a level part working than a slanting parcel building. Be that as it may, the expansion in shear was observed to be very more noteworthy in short segments contrasted with normal ones and a gigantic minute ought to be endured by slanting part structures. The more prominent firmness of the structure was likewise uncovered by nonstraight static (Push-Over) investigation. As indicated by the outcomes, short segment are required to have more safe areas and are proposed to be strengthened with more bars. Likewise, more steel ought to be utilized as stirrups than as longitudinal bars. Likewise to exist structures, shear limit of short segments ought to be retrofitted by FRP, Steel Coat or different materials.

Zaid Mohammada (2016) Confined structures built on slope inclines indicate unexpected basic conduct in comparison to that on the plain ground. Since these structures are unsymmetrical in nature, subsequently draw in huge measure of shear powers and torsional minutes, and show unequal circulation because of changing segment lengths. In present investigation, two unique setups of slope structures have been displayed and broke down utilizing ETABS v 9.0 limited component code. A parametric report has been completed, in which slope structures are geometrically differed in stature and length. Taking all things together.

\section{PROBLEM IDENTIFICATION}

Review of different papers related to the subject was done. Some problems were identified such as:-

$>$ In past, researchers have studied the shear behavior of multi storey buildings for different seismic zones.

> Design of earthquake resistant multi storey RCC building on sloping ground with varying of floor height and number of bays was done.
The previous researches were done for other seismic zones like zone IV and V by considering only square geometry of high rise buildings.

\section{OBJECTIVES}

$>$ To analyse problems of high rise RCC buildings considering earthquake Zone III in different geometries using Staad Pro V8i software.

$>$ To analyse the building at three different sloping grounds (i.e., $0^{\circ}, 10^{\circ}$ and $15^{\circ}$ ).

\section{CONCLUSION}

Analysis and design of space building frame for seismic loading and wind pressure is very essential these days because construction of high rise buildings. It is also necessary to construct a economic and more durable structure. It is possible by availability of various software and specialized programs. By using these software we can design a low weight reinforce structure which life is very good. These structures are more economical and safe by different forces acting on the building structure such as seismic load, snow load and wind pressure etc.

Reinforced concrete (RC) frame buildings are most common type of constructions resting on plane and sloping ground (hilly area) in India. There buildings are subjected to several types of forces during their lifetime, such as static forces due to dead and live loads and dynamic forces due to the wind and earthquake.

Results from seismic analyses performed on three RC buildings with three different ground slopes $\left(0^{\circ}, 10^{\circ}\right.$, $15^{\circ}$ ) has been carried out by using static method. The top storey displacement and the footing reaction, axial force, shear and moment action induced in columns and beams have been studied to investigate the influence of sloping ground on structural performance of building frame.

\section{REFERENCE}

1. Agrawal P. and Shrikhande M. 2006, Earthquake resistant design of structures (Prentice-Hall of India Private Limited, New Delhi, India) Applied Technology Council (1996): Seismic Evaluation and Retrofit of Concrete Buildings, ATC-40, Vol. 1.

2. Athanassiadou C. J, 2008, Seismic performance of $\mathrm{R} / \mathrm{C}$ plane frames irregular in elevation, Engineering Structures 30(2008):1250-1261. 
3. Birajdar B. G., and Nalawade S. S. 2004. Seismic Analysis of Buildings Resting on Sloping Ground. In Thirteenth World Conference on Earthquake Engineering (13WCEE). Vancouver, Canada, Paper No.1472.

4. Birajdar B. G., Nalawade. S. S., 13WCEE 2004 Seismic analysis of buildings resting on sloping ground. Conference on Our World in Concrete \& Structures: 29 - 30 August 2002,Singapore.

5. BIS. (2002). IS 1893 (Part 1) Indian Standard criteria for Earthquake Resistant Design of structures, Part 1: General Provisions and buildings (Fifth Revision). New Delhi, Bureau of IndianStandards.

6. Bozorgnia Y, Bertero V, "Earthquake Engineering: From Engineering Seismology to Performance-Based Engineering", III CRC Press, 2004.

7. Chandwani Vinay, Agrawal Vinay, Gupta and Naveen Kumar (2012), "Role of Conceptual Design in High Rise Buildings.”, Vol. 2, Issue 4, July-August 2012, pp.556-560.

8. Emraherduran (2008), “Assessment of current nonlinear static procedures on the estimation of torsional effects in low-rise frame buildings in sloping ground", Engineering Structures 30 (2008):2548-2558.

9. Gourabi, A. and Yamani, M. (2011) Active Faulting and Quaternary Landforms Deformation Related to the Nain Fault on sloping ground. American Journal of Environmental Sciences, 7,441-447.

10. Guan Y. H., et al. (2011) Studied on the Earthquake Disaster Reduction Information Management System and Its Application. International Journal of Intelligent Systems and Applications, Vol-1, pp51-57.

11. Hajra B and Godbole P. N. (2006). "Along Seismic Load on Tall Buildings Indian Codal Provisions." 3NCWE06 Kolkata, pp285-292.

12. IS 1893 (Part-I) 2002: Criteria for Earthquake Resistant Design of Structures, Part-I General Provisions and Buildings, Fifth Revision, Bureau of Indian Standards, New Delhi.

13. IS 875(1987), Indian Standard Code of practice for Design loads for buildings and structures, Bureau of Indian Standards, New Delhi. Ashraf Habibullah, Stephen Pyle, Practical three- dimensional non-linear static and dynamic analysis, Structure Magazine, winter, 1998 FEMA-356(2000), Pre standard and Commentary for the seismic Rehabilitation of buildings, American Society of Civil Engineers,USA.

14. KazemShakeri (2012),"An adaptive modal pushover procedure for asymmetric-plan buildings", Engineering Structures 36 (2012), pp.160-172.

15. Kumar, S., and Paul, D. K. (1998). A Simplified Method for Elastic Seismic Analysis of Hill Buildings. Journal of Earthquake Engineering 2 :) 2),241-266.

16. Lee Han Seon ,Dong Woo Kee, 2007, Seismic response characteristics of high-rise RC wall buildings having different irregularities in lower stories with sloping ground, Engineering Structures 29(2007):3149-3167.

17. Montgomery C J. "Influence of seismic effects on seismic design", Canadian Journal of Civil Engineering 1981; 8:pp31-43.

18. Nalawade S. S. "Seismic Analysis of Buildings on Sloping Ground," M.E. Dissertation, University of Pune, PuneDec-2003.

19. Pandey A. D, Prabhat Kumar, Sharad Sharma., International Journal of Civil and Structural Engineering Vol. 2, No. 2, 2011 Seismic soilstructure interaction of buildings on hillslopes. 